\title{
Public Sector Responses to Climate Change: Evaluating the Role of Scottish Local Government in Implementing the Climate Change (Scotland) Act 2009
}

\author{
Tony Jackson \\ School of the Environment \\ University of Dundee

\section{William Lynch} \\ School of the Environment \\ University of Dundee
}
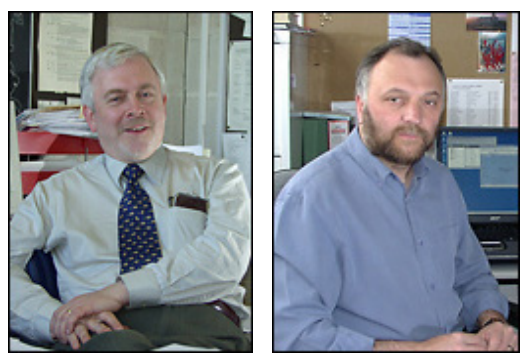

\begin{abstract}
Effective climate change actions demand collaborative action from public bodies at all levels, placing local governance at the forefront of delivery. Scottish legislation imposes some of the most demanding legally-binding requirements for reducing greenhouse gas emissions currently to be found anywhere in the world. The new climate change obligations on Scottish local government are reviewed in the context of current Scottish emissions and UK energy policies. Analysis indicates that the pattern of carbon consumption rather than its production must be targeted, and that local government is well-placed to deliver many of the policies to this end. Case studies of Fife and Highland Councils show how Scottish local authorities (SLAs) are planning to discharge their climate change mitigation and adaptation responsibilities. Energy efficiency is driving the mitigation of carbon consumption, while new techniques for measuring carbon footprints are being used to adapt the development process to a low carbon mode. SLAs must pursue low-cost local climate change solutions not just to enhance the resilience of Scottish communities but also to demonstrate the feasibility of such approaches for local
\end{abstract}


governance systems elsewhere in the face of growing financial constraints. Recent changes in Scottish waste management practices indicate the potential in this respect.

\section{Keywords}

Climate Change (Scotland) Act 2009, Scottish local government, climate change mitigation and adaptation policies

\section{Introduction: Climate Change and the Role of Local Governance}

Climate change driven by anthropogenic actions cannot be constrained solely through the operation of market forces. Sustainable management of global common-pool resources such as the atmosphere requires multilateral environmental agreement between sovereign States to provide a framework for concerted actions to supplement the workings of the market (Mabey et al, 1997). Local councils must then assume responsibility for delivering their share of any State's international commitments on climate change, serving as arbiters of competing demands from their own inhabitants for access to these shared resources. In practice, this places systems of local governance at the forefront of efforts to tackle global warming.

Local public services (such as land use controls, local transport systems, social housing, water supplies, education, health, local welfare and recreational facilities, sewerage and waste management, libraries and information systems, protective services and emergency planning operations) play a major role in shaping the demands placed by local communities on the atmosphere and in determining their resilience to climate change. This paper reviews the implications of climate change for one jurisdiction's local government sector. It considers how Scottish local authorities (SLAs) are responding to some of the world's most demanding statutory obligations for delivering a low carbon economy, set out in the Climate Change (Scotland) Act (CCSA) 2009 (SP, 2009), and identifies some of the lessons that can be drawn from Scottish experiences for local government practitioners in other jurisdictions.

The argument of the paper is delivered in five parts. The next section provides a brief overview of Scottish greenhouse gas (GHG) emissions and the measures being taken at UK level to stimulate a low carbon energy market. This allows the main policy implications of addressing climate change to be identified, and the statutory powers taken by the Scottish Government for this purpose, including the climate change duties now 
imposed on SLAs, to be outlined. We then examine some initial SLA responses to these new duties, focusing on two sets of policy interventions. The primary set consists of mitigation actions, targeted at substantial reductions in GHG emissions. The secondary set involves adaptation measures, which ameliorate the inescapable impacts of ongoing climate change. A concluding section evaluates the opportunities and threats climate change presents for SLAs.

\section{The Current State of Play: Trends in Scottish GHG Emissions and Reform of the UK Energy Market}

\section{Current trends in Scottish GHG emissions}

Table 1 indicates recent trends in the level of GHG emissions attributable to Scottish sectors of production. Total emissions calculated on this basis are shown to have fallen by $18.7 \%$ between the baseline average over $1990-95$ and 2007. Business and industry, followed by waste management, made the largest absolute reductions, together accounting for $60 \%$ of the total fall. Energy supply's smaller reduction was counterbalanced by an increase in emissions from transport, allowing the total share of Scottish emissions generated by these two sectors to rise from a baseline contribution of just over $50 \%$ to $62 \%$ in 2007 . Land use, land use change and forestry (LULUCF) activities serve as a carbon sink, and their offsets rose appreciably over this period. In 2007 Scottish LULUCF offsets were far larger than those for the UK as a whole, reflecting the importance of the Scottish forestry sector.

The data in Table 1 require a small adjustment to take account of the effects of the Emissions Trading System (ETS) over this period. Introduced in 2005, this sets a cap on the emissions of major energy intensive undertakings within the European Union (EU). In Scotland nearly one hundred large industrial installations, including electricity generators, refineries and heavy industry, which account for around $40 \%$ of total Scottish GHG emissions, are allocated allowances under the ETS which can be traded to make up shortfalls or realise surpluses. Over the past few years, Scotland has been a small net purchaser of ETS allowances, and this has slightly reduced its net attributable GHG emissions below the actual ones reported. 
Table 1. Scottish GHG emissions, change from base (1990-95 annual average) to 2007 (not adjusted for trading in the EU ETS).

\begin{tabular}{|c|c|c|c|c|c|c|}
\hline Sector & $\begin{array}{c}\text { Baseline } \\
\text { annual average } \\
(1990-95) \mathrm{Mt} \mathrm{CO}_{2} \mathrm{e}\end{array}$ & $\begin{array}{c}2007 \\
\mathrm{Mt} \mathrm{CO}_{2} \mathrm{e}\end{array}$ & $\begin{array}{c}\text { Change } \\
\text { (baseline to } \\
2007) \\
\mathrm{Mt} \mathrm{CO}_{2} \mathrm{e}\end{array}$ & $\begin{array}{c}\text { Change } \\
\text { (baseline to } \\
2007) \\
\%\end{array}$ & $\begin{array}{c}\% \text { of Scottish } \\
\text { net } \\
\text { emissions } \\
2007\end{array}$ & $\begin{array}{c}\% \text { of UK net } \\
\text { emissions } \\
2007\end{array}$ \\
\hline Energy supply & 22.35 & 20.59 & -1.76 & -7.9 & 36.2 & 9 \\
\hline $\begin{array}{c}\text { Transport (including } \\
\text { international aviation \& } \\
\text { shipping) }\end{array}$ & 13.21 & 14.73 & 1.52 & 11.5 & 25.9 & 8 \\
\hline Business \& Industry & 12.46 & 7.68 & -4.78 & -38.4 & 13.5 & 7 \\
\hline Agriculture & 9.72 & 7.69 & -2.03 & -20.9 & 13.5 & 16 \\
\hline Residential & 7.79 & 7.20 & -0.59 & -7.6 & 12.7 & 9 \\
\hline Waste management & 5.77 & 2.64 & -3.13 & -54.2 & 4.6 & 12 \\
\hline Public & 1.24 & 0.81 & -0.43 & -34.7 & 1.4 & 8 \\
\hline $\begin{array}{l}\text { Land use, land use } \\
\text { change \& forestry }\end{array}$ & -2.52 & -4.44 & -1.92 & 76.2 & -7.8 & 249 \\
\hline $\begin{array}{c}\text { Total Scottish net } \\
\text { emissions }\end{array}$ & 70.01 & 56.90 & -13.11 & -18.7 & 100.0 & 8 \\
\hline
\end{tabular}

*negative. Source: SG, 2010d

A more fundamental issue confronting policy-makers relying on these statistics as a management tool for monitoring Scottish climate change performance is that they only record the GHG emissions attributable to a jurisdiction's production of goods and services. They do not indicate what contribution its consumption of goods and services makes to GHG emissions, since a proportion of Scotland's domestic needs are met by imports while part of its output is exported. To convert the data from a production to a consumption base, GHG emissions attributable to imports must be added, those attributable to exports deducted, and LULUCF offsets disregarded (Helm et al, 2007). When these adjustments are made using one of the growing number of multi-regional input-output (MRIO) packages being developed to model global GHG emissions (see, for example, Dawkins et al, 2010), Scotland's GHG emissions measured in terms of consumption are shown to have risen by 14\% between 1992 and 2006 (SG, 2010d: para.5.5). The difference in these two trends over the fifteen year period, which has seen an $18.7 \%$ fall in GHG emissions generated physically within Scotland converted into a $14 \%$ rise after taking into account domestic consumption of goods and services obtained from all sources, provides a clear indication of the significance of the problem of carbon leakage in addressing climate change. 
This phenomenon first came to prominence during multi-lateral negotiations over proposals for binding agreements on GHG emissions embodied in the Kyoto Protocol (Barker \& Johnstone, 1998). A number of parties to the negotiations raised concerns that an agreement restricting the GHG emissions of developed countries might lead to a loss of business to jurisdictions without emissions controls. If such effects became widespread after the implementation of the Kyoto Protocol, the net change in global GHG emissions might prove far smaller than the gross reductions in developed countries. Businesses would be tempted simply to switch the location of their production to uncontrolled jurisdictions, continuing to sell the same products to their consumers as imports rather than as domestic output, creating what came to be termed carbon leakage.

As the Scottish situation demonstrates, carbon leakage exists without the assistance of asymmetrical international GHG emission controls. Divergent trends in the production and consumption metrics of GHG emissions are an integral aspect of mature open economies (Brinkley \& Less, 2010). They arise from structural changes within these economies as their product mix is modified in response to long-term shifts in global market parameters. Rising energy costs and widespread improvements in energy efficiency have been accompanied by ongoing de-industrialisation and a switch to service sector activities, with many previously domestically manufactured goods now being imported. Globalisation of trade allows the level of GHG emissions generated by productive activities within a mature economy such as Scotland to be decoupled from the carbon footprint created by its consumers. This footprint continues to rise in line with the higher living standards that stimulate increasing domestic consumption of goods and services, the sourcing of which is not confined to Scotland but met from the most competitive location.

The ease with which a mature economy is capable of decoupling the linkages between the emissions generated by its pattern of consumption from those generated by its production base indicates that strategies for delivering a low carbon economy must modify the behaviour of consumers as well as producers. Furthermore, the scale of carbon leakage that international trade already facilitates, far from serving to discourage international climate change agreements, should instead confirm the need to address the problem on a global basis rather than through an uncoordinated set of individual initiatives. In this respect, the EU Single Market provides a helpful halfway house, setting broadly comparable climate change policy parameters for businesses operating 
within its Member States and in return allowing them free access to its 501 million consumers (Schreurs et al, 2009).

\section{Reform of the UK energy market}

In choosing an optimal mitigation pathway, the policy-maker's initial task is to estimate under conditions of uncertainty the basic shape of two critical functions: the benefit function that measures the damage avoided by mitigating anthropogenic GHGs; and the cost function which measures the amount of resources required to deliver various levels of abatement. The sensitivity of either function to different mitigation targets should condition the type of strategy favoured (Helm, 2010a). If policy-makers envisage that the marginal damage function is liable to rise steeply in the absence of effective abatement measures whilst the marginal costs of policies to this end remain relatively insensitive to the scale of mitigation required, they should favour quantitative GHG targets delivered by policy instruments such as the emissions caps embodied in the EU ETS, and accept the implicit carbon prices resulting. Conversely, if they consider that marginal costs are liable to rise precipitately as the scale of mitigation increases, whereas the marginal damage function appears fairly flat over feasible target ranges, it makes more sense to select an acceptable price for carbon externalities which can then determine the affordable level of abatement and identify the mitigation options that remain viable.

Recent UK and Scottish Government policy choices in this respect have been driven by the Stern Review (2006), commissioned by the UK Treasury to consider the economics of climate change. Stern's findings have convinced British policy-makers of the need for early and substantial climate change interventions based on quantitative targets. Arguing in favour of such an approach, the previous UK Labour government stated:

if left unchecked, climate change presents an increasing threat to our security and prosperity. Lord Stern has shown that if we do not take action, the longer term costs of climate change will vastly outweigh the costs of early movement to a low-carbon, climate resilient economy (DECC, 2010a:10).

Stern's analysis has been challenged (for example by Helm, 2008), but the current UK and Scottish administrations still favour the use of statutory emissions targets rather than explicit carbon prices for their mitigation strategies.

The UK fiscal instruments supporting a shift towards a low carbon energy market reflect this emphasis on quantitative goals rather than cost-effective options. Table 2 ranks them 
in terms of their marginal cost per tonne of carbon savings. The range of implicit carbon prices so calculated lends weight to claims that this approach to mitigation facilitates rentseeking behaviour on the part of generators (Helm, 2010b). The costs of saving carbon range from $£ 3.26$ per tonne of $\mathrm{CO}^{2}$ equivalent for the Climate Change Levy on Fuel Oil up to $£ 460$ for Feed-in Tariffs for Microgeneration and possibly more for the Renewable Heat Obligation. These huge differences are compounded by the fact that some of the more expensive measures serve as potential substitutes for much cheaper alternatives. Thus, the carbon savings delivered by the Renewables Obligation and the Feed-in Tariffs for Microgeneration "may result in cheaper carbon reductions elsewhere in the EU not happening, since all emissions are under the ETS cap" (McIlveen, 2010: 47).

Table 2. Implied Carbon Prices of UK Fiscal Instruments Used for Carbon Mitigation

\begin{tabular}{|c|c|c|}
\hline Policy & Price $\left(£ t \mathrm{CO}^{2} \mathrm{e}\right)$ & Who pays \& how? \\
\hline Climate Change Levy: Fuel Oil & 3.26 & Business customers through energy bills \\
\hline Climate Change Levy: Coal & 5.03 & Business customers through energy bills \\
\hline Climate Change Levy: Gas & 8.63 & Business customers through energy bills \\
\hline Climate Change Levy: Electricity & 10.93 & Business customers through energy bills \\
\hline Carbon Reduction Commitment & 12 (fixed for 3 yrs) & Non-energy-intensive large businesses \\
\hline EU Emissions Trading Scheme & 14 approx. (variable) & $\begin{array}{l}\text { Power companies and other energy-intensive } \\
\text { industries, passed through to all customers }\end{array}$ \\
\hline Air Passenger Duty & $25-320$ & All passengers, on ticket \\
\hline Fuel Duty - Red Diesel & 41.79 & Agricultural businesses \\
\hline Renewables Obligation & 130.25 & Power companies, passed to all customers \\
\hline Fuel Duty - Diesel & 217.45 & All drivers, at pump \\
\hline Fuel Duty - Petrol & 248.65 & All drivers, at pump \\
\hline Feed-in Tariffs for Microgeneration & 460 & Consumers through bills \\
\hline Renewable Heat Incentive & Not clear: very high & Consumers through bills \\
\hline Carbon Capture and Storage Levy & Not clear & Consumers through bills \\
\hline
\end{tabular}

Source: Mcllveen, 2010

Some rationalisation of these arrangements is underway (DECC, 2010b). A floor price for carbon is being introduced, offering power utilities greater incentives to switch from carbon-intensive forms of generation than provided by the current ETS traded price. Other measures include employing a 'contract for difference' system for feed-in tariffs that should offer a more cost-effective way of stimulating low carbon capacity from generating sources of widely differing scale; further incentives to encourage the additional capacity needed to ensure security of supply as the National Grid becomes more dependent on intermittent power sources such as wind farms; and the use of an emissions performance standard to limit the amount of carbon that coal-fired generating 
stations can emit. Even with these measures, the UK Government still expects the price of electricity to rise in real terms by $52 \%$ over the next twenty years, from $£ 118$ per megawatt hour to $£ 179$ (Lea, 2011).

\section{Implications for SLAs of the Climate Change (Scotland) Act 2009}

\section{Policy implications for SLAs of adopting a low carbon strategy}

The analysis in the previous section offers some pointers on how SLAs should discharge their climate change responsibilities. Firstly, it must be apparent that mitigation at any price cannot be an end in itself. Use of atmospheric resources is characterised by the allocative problem of global commons. Individual States cannot be excluded from accessing such resources, while their actions impose consequences for all users. This creates a free-rider hazard. Irresponsible States cannot be prevented from sharing the benefits delivered by the actions of responsible States, nor can the costs of selfish behaviour be confined to the perpetrators (Barkin \& Shambaugh, 1996).

This means that Scottish efforts to reduce its GHG emissions will do little to ameliorate the effects of global warming for Scotland or for the rest of the world, unless the strategies deployed are sufficiently cost-effective to make similar abatement measures attractive to others (Mabey et al, 1997). A jurisdiction pioneering a path-breaking mitigation strategy must justify this in terms of the effect its successful implementation would create, by demonstrating to others that a low carbon economy is feasible and worthwhile (rather than expensive and difficult). Uncommitted jurisdictions need to be convinced of the logic of Scotland's approach in order to create the momentum favouring collective actions to realise mutual benefits. Failure to deliver a viable strategy would simply reinforce free-rider arguments.

Secondly, the key variable for measuring the performance of a mitigation strategy should be its impact on the consumption of goods and services generating GHG emissions, not their production. Delivering zero carbon outcomes for a jurisdiction's productive activities would do little to reduce global warming if its consumers respond to any resulting domestic price hikes simply by meeting their needs through additional imports from unconstrained cheaper sources. Mitigation policies should instead be focused on modifying the choices made by a jurisdiction's commercial, industrial, voluntary and public sectors and by its individual households in their capacity as consumers of carbon- 
emitting goods and services rather than as their producers. Such policies already apply to energy and fuel usage, which as Table 1 indicates currently account for $62 \%$ of Scottish GHG emissions. Table 2 confirms that consumers ultimately bear the cost of reducing the carbon profile of these sectors.

There is evidence that extending such an approach to the rest of the economy would prove cost-effective. In their MRIO modelling of the UK economy which considers all the linkages between resource flows and usages, Dawkins et al (2010) review alternative production and consumption strategies offering quick-win carbon savings up to 2020 . They conclude that "overall, the consumption or resource sufficiency strategies delivered a much greater decrease in GHG emissions than the production based strategies" (Dawkins et al, 2010, para.5.2). Research commissioned by the Scottish Government (AEA, 2008) identifies carbon capture and storage (CCS) and improved vehicle technologies as offering potentially the largest carbon savings for Scotland, followed by banning biodegradable waste from landfills and promoting further afforestation. Only CCS amongst these preferred options counts as a production strategy and this was not considered by the Dawkins et al (2010) study because the technology supporting it remains unproven.

\section{Statutory climate change duties for SLAs}

Scotland retained its own legal, religious and education system following the 1707 Act of Union, and the past century has seen increasing administrative devolution of other areas of governance. This culminated in 1999 in the creation of an elected Scottish Parliament and Government able to exercise a wide range of devolved legislative and executive powers. Although energy policy is one of the reserved powers retained by the United Kingdom (UK) Government, Scottish Ministers exercise devolved authority over statutory land use policy and share authority over transport policy with their UK counterparts. They also have full responsibility for funding and overseeing Scottish local government services, meeting $80 \%$ of their cost through grants to SLAs. In practice this means that the Scottish Government can use its legislative powers, as demonstrated by the CCSA, to inform, guide and regulate most public sector activities relating to climate change within its boundaries, even where certain governmental powers are technically exercised either at a UK or a European Union (EU) level. 
Part 1 of the CCSA creates a statutory obligation to reduce Scottish GHG emissions by $80 \%$ in 2050 , with an interim reduction target of $42 \%$ by 2020 (SP, 2009). To enable these goals to be realised, Scottish Ministers are required to use secondary legislation to set annual targets from 2010 until 2050. They are also obliged to take advice on how to set carbon budgets to hit such targets, initially from the UK Committee on Climate Change set up as part of the UK Climate Change Act 2008 (UK Parliament, 2008). Part 2 of the Scottish Act allows Scottish Ministers to establish their own expert committee or to designate an existing body to fulfil this function.

Part 3 of the CCSA obliges Scottish Ministers to report to the Scottish Parliament on Scottish GHG emissions and on the progress being made towards the targets set out in the legislation (SG, 2009a). Part 4 places climate change duties on Scottish public bodies, and enables Scottish Ministers to issue statutory instruments placing further duties on such bodies in relation to climate change. Part 5 contains further statutory provisions on climate change which address adaptation, forestry, energy efficiency and waste reduction. Part 6 sets out provisions for public engagement with the implementation of climate change legislation, and makes provisions for carbon assessment, including accounting for carbon trading.

The parallel UK legislation sets a slightly less ambitious interim 2020 reduction target of $34 \%$. It also excludes aviation and shipping from its targets, and sets them on a quinquennial rather than annual basis. Whereas the UK framework allows borrowing of up to $1 \%$ from the following carbon budget period, no such facility is available under the Scottish one. The UK framework also allows the purchase of credits to meet its carbon budgets, subject to advice from its Committee on Climate Change, but the Scottish one sets a prior limit of $20 \%$ of the emissions reduction effort on the purchase of such credits.

The climate change duties placed on Scottish public bodies by Part 4 of the CCSA came into effect at the start of 2011. These require that the public sector in Scotland, in exercising its functions, must act in the way:

- best calculated to contribute to the delivery of the mitigation targets set in or under Part 1;

- best calculated to help deliver any programme laid before the Scottish Parliament under section 53 (which requires Scottish Ministers to produce adaptation programmes); and that they consider most sustainable. 
Guidance in relation to these duties (SG, 2011) stresses the importance of undertaking these duties effectively. It emphasises the need for changes in existing processes and procedures to allow pro-active responses that set targets and milestones and integrate climate change into their business practice. SLAs and other Scottish public bodies are expected to draw on their corporate skills to meet these statutory obligations, utilising their expertise in business planning, staff management, estate management and procurement.

As well as ensuring that efforts to address climate change are mainstreamed within their own organisations, SLAs are expected to ensure that these aims are endorsed within the communities they serve. To this end, they must take action to strengthen their governance, leadership and commitment in regard to climate change, so that suitable community strategies and action plans can be put into effect, including partnership arrangements with other public bodies and local organisations in their area. The guidance also expects public bodies to incorporate appropriate techniques into their decisionmaking, so that they can undertake effective assessment of the carbon impacts of policy options, adopt pathways capable of realising their climate change plans, and provide an audit trail of their actions for compliance reporting purposes.

\section{Policy Instruments for Discharging SLA Climate Change Duties}

\section{SLA mitigation measures}

Since 2007, all SLAs have been signed up to the Scottish Climate Change Declaration (SCCD, 2011). Launched in 2000, this voluntary initiative requires signatories to acknowledge the consequences of climate change and to co-operate with others in undertaking many of the climate change actions subsequently set out as statutory duties in the CCSA, including the production of annual reports on the performance of their carbon management activities. SLAs now have to build on these reports by publishing action plans for mitigation and adaptation demonstrating how they will discharge their CCSA responsibilities.

The research capacity available to SLAs to meet the technical requirements for these voluntary Scottish Climate Change Declaration reports, as well as for the new statutory plans and compliance statements meeting their CCSA duties, has been steadily enhanced over the past decade. Sources of expertise now include the Scottish Climate Change 
Impacts Partnership (SCCIP, 2011) and the Scottish and Northern Ireland Forum for Environmental Research (SNIFFER, 2011). Additional capacity is provided by the Scottish Government's own environmental agencies, Scottish Natural Heritage and the Scottish Environment Protection Agency, as well as through the UK's Hadley and Tyndall climate research centres.

Fife Council has a population of 360,000 , making it Scotland's third largest local authority. It illustrates the range of corporate climate change mitigation activities undertaken by SLAs. The council's most recent Annual Progress Report published as part of its commitments under the Scottish Climate Change Declaration (FC, 2010) sets out its current climate change activities. Those restricted to Fife Council's own in-house operations are channelled through its Council Plan. Supplementing these internal management mechanisms, the council is engaged in various community-wide low carbon initiatives across Fife. Most of these draw on existing Community Plan provisions, through which a Fife Environmental Partnership has been established.

The council's system for monitoring and controlling its own carbon footprint has received Carbon Trust Standard approval. A Carbon Emissions Reduction Plan was launched in 2009, and this now drives the majority of the council's in-house mitigation efforts, taking on board the findings of carbon emission audits of individual council services. Council procurement services have begun to trial a Whole Life Costing tool for estimating the impact of its procurement options on GHG emissions, and council officers are developing a Carbon Emissions Impact Assessment toolkit to quantify the climate change implications of council proposals (FC, 2010).

Recent audits indicate that Fife Council's annual carbon footprint is around 110,000 tonnes $\mathrm{CO}^{2}$ equivalent (FC, 2010). The energy demands of the council's buildings account for $70 \%$ of this footprint, the two other main contributors being energy needs of its other infrastructure (12\%) and fuel requirements for its vehicle fleet $(13 \%)$. This represents a typical footprint for the direct emissions of SLAs, helping explain the emphasis placed on public sector schemes in Scotland's Energy Efficiency Action Plan (SG, 2009c).

The EU Directive on Energy Performance of Buildings (CEC, 2002) was transposed into Scottish law through amendments to Scottish building regulations (SP, 2008). Since 
January 2009, all large public buildings (covering an area over $1,000 \mathrm{~m}^{2}$ ) are required to display an Energy Performance Certificate (EPC). A revised EU Directive on the energy performance of buildings has recently been issued (CEC, 2010), and Scottish Ministers are due to implement the necessary further changes to Scottish building regulations.

Data from the current EPC system highlights the poor energy efficiency of Scottish public sector buildings, the majority of which are operated by SLAs. A recent audit report observes that this:
illustrates the scale of the challenge in reducing emissions from the existing public sector estate. Over $70 \%$ of large public sector buildings have an EPC rating of $\mathrm{E}$ to $\mathrm{G}$ [poor to very poor], with only $4 \%$ rated at A or B [very good or excellent](Audit Scotland, 2010: para. 57).

The problem of poor energy efficiency in the face of rising energy costs is not confined to the public sector. Evidence of the scale of the problem amongst large UK organisations not covered by the ETS or by existing Climate Change Agreements (which are targeted at energy-intensive undertakings) has prompted the UK Government to introduce a new Carbon Reduction Commitment (CRC) Energy Efficiency Scheme. This is aimed at less energy-intensive businesses and public sector organisations that use over 6,000 megawatt hours of metered energy per annum.

The CRC will apply to 27 of the 32 SLAs. Initial proposals for the scheme involved a cap-and-trade arrangement similar to the ETS that would have allowed participants to trade their allowances and retain any profits. Fife Council was the only SLA that participated in a trial carbon trading scheme covering 34 local authorities across the UK (Bradshaw \& Johnston, 2009) in order to test out the opportunities this presented. The CRC has since been amended (DECC, 2010c) so that only its penalty elements remain.

Organisations subject to the CRC will be required to audit all their GHG emissions. This information will be used to allocate allowances that must be purchased at an initial price of $£ 12$ per tonne of $\mathrm{CO}^{2}$ equivalent (broadly in line with the current cost of acquiring allowances under the ETS). The audited data will also be used to compile and publish an overall performance table, ranking each of the participants. Audit Scotland (2010: para.68) estimates that Scottish public bodies face an initial overall financial cost of buying allowances amounting to $£ 20$ million, ranging from $£ 25,000$ for a small SLA to over $£ 3$ million for Scottish Water. The publicity given to their relative performance 
under the CRC is intended to reinforce the effects of financial sanctions in promoting increased energy efficiency.

Domestic energy demands for space and water heating and power account for $29 \%$ of all Scottish energy consumption (SG, 2009c: 3). In addition to raising their in-house energy efficiency, SLAs will also be expected to take strategic ownership of a new domestic housing energy efficiency scheme, termed Green Deal, which is part of the Energy Security and Green Economy Bill (DECC, 2010d). The Green Deal is targeted at housing in the public and private rented sector, as well as owner-occupied homes, suffering low energy-efficiency. It allows energy improvements of up to $£ 7,000$ per dwelling to be implemented without upfront payments: part of the subsequent energy savings by households is diverted to meet the cost of these improvements.

The Green Deal (which has also been extended to small businesses) is targeted towards funding energy efficiency measures that generate more savings than they cost, based on an independent assessment by an accredited adviser. Only accredited installers may participate in the scheme. Although Scottish households in owner-occupied dwellings currently already have access to a range of incentives to improve the energy efficiency of their properties (SG, 2009c), the situation for tenants of local authority and private rented accommodation is less clear-cut, since landlords may have little incentive to undertake energy efficiency improvements if tenants are responsible for meeting their own energy bills. The scheme includes powers to require landlords to honour reasonable requests from their tenants for such improvements, where they qualify for Green Deal assistance.

A recent survey indicated that $21 \%$ of private sector rented accommodation in England had EPC ratings in the lowest categories, 'F' or 'G' (Hayman, 2010: 11). Under the new Bill, all UK local authorities will be empowered to require landlords owning properties that fall into the worst performing categories to undertake all energy efficiency improvements for which financial support is available. SLAs remain important providers of affordable rented accommodation, even though their stock of social housing has been significantly reduced in recent decades by right-to-buy legislation. Some of their housing stock also suffers from poor energy efficiency, and part of the intention of this new scheme is to make local authorities promote area-wide initiatives to raise the energy efficiency of all housing stock eligible for assistance, including their own. 
Measures such as the Green Deal ease the problem of fuel poverty, which continues to be a major obstacle to implementing climate change mitigation through measures that drive energy costs up for domestic consumers (Dresner \& Ekins, 2006). The most recent estimates put the number of households in Scotland who are considered to suffer from fuel poverty at 618,000 (SG, 2009c: 11). Powers included in the new Energy Security and Green Economy Bill would give local authorities access to an Energy Company Obligation (ECO) designed to help such households. The UK Minister in charge of the Bill is reported as saying that councils would have a key role in ensuring that the ECO was effectively spent for this purpose through new forms of engagement with the private sector, "with councils selecting a few preferred partners, who would deliver the Green Deal in their area according to street-by-street plans drawn up by councils prioritising the most vulnerable and the low-quality housing in their area" (Hayman, 2010: 11).

\section{SLA adaptation measures}

Highland Council was the first SLA to publish an adaptation action plan in anticipation of its new CCSA climate change duties (HC, 2010). Applying the guidance contained in the Scottish Climate Change Adaptation Framework (SG, 2009b), the plan focuses on increasing the resilience of Highland communities to climate change. Highland Council is easily the largest SLA by area, with many of its 220,000 residents located in isolated settlements. Some of its montane, riverine and coastal communities already have an exposure to natural hazards that exceeds other parts of the UK. The adaptation action plan starts by assessing past climate trends and possible future climate scenarios for these communities.

Changes in temperature and precipitation over recent decades have witnessed a significant increase in the area's growing season (HC, 2010: 19), but one of the major future climatic imponderables is the impact of climate change on the Meridional Overturning Circulation. This ensures that much of the west coast of the Highlands enjoys a much milder (and wetter) climate than its latitude (parallel to northern Labrador on the other side of the North Atlantic) would indicate. Research suggests that the warm North Atlantic Drift it produces might be weakened by ongoing climate change (HC, 2010: 42). This counter-intuitive possibility of much colder waters poses a significant risk for the western Highlands, in terms of its impact on land- and sea-based activities. 
As part of its preparations for an adaptation plan, the council organised a series of workshops for its own service divisions and for community representatives. These provided information on what might be the potential effects of climate change on the Scottish Highlands, and also allowed the council to receive feedback on what participants felt were the main local threats and opportunities arising from these effects. The results of such consultations are listed in section 4 of the action plan (HC, 2010: 50-68). They display a wide range of views on possible impacts, confirming the need for ongoing research on climatic change, particularly in an area with large variations in climate and habitat which is occupied by many isolated communities heavily reliant on local public services.

Section 5 of the action plan (HC, 2010: 70-79) is arranged around five commitments. These require the council to:

- demonstrate leadership;

- build on its knowledge base;

- embed climate change issues into existing policy structures and processes;

- inform and communicate the need for action, targeting those at greatest risk; and

- co-operate with relevant stakeholders to identify the most appropriate forms of adaptation.

These commitments are supported by a set of 24 action statements, which identify the responsible service and provide a review date. These are graded accorded to current status: completed or on target; progress with some slippage; no significant progress; or to be programmed. Each is also provided with a brief explanatory comment. The final section dealing with monitoring and evaluation notes that actions within the plan "will be refined through the consultation process and will be SMART: Specific, Measurable, Agreed, Realistic and Time-Bound" (HC, 2010: 77).

Although the Scottish Highlands presents some adaptation challenges that are unique to the area, the general issues identified echo points made in a recent House of Commons committee report on climate change adaptation arrangements. This acknowledged that climate change impacts would vary considerably from location to location, warranting reliance on local decision making organised and co-ordinated through systems of local governance. It also stressed the role of the planning system, recommending that all local authorities should be encouraged "to use planning obligations to require developers to 
take adaptation measures that benefit their new developments and the wider community" (EAC, 2010: para.42).

The role of the statutory planning system in promoting effective climate change mitigation and adaptation extends well beyond concerns about planning obligations. By modifying the shape of the built environment, planning processes can promote sustainable growth designed to minimise resource use and carbon emissions and increase resilience to climate change (Wilson \& Piper, 2010). A recently formed UK pressure group offers local planning authorities guidance and model policies on climate change, stating that spatial planning can make a major contribution "by shaping new and existing developments in ways that reduce carbon dioxide emissions and positively build community resilience to problems such as extreme heat or flood risk" (PCCC, 2010: 2).

The Scottish approach to spatial planning exemplifies this philosophy. The Planning etc. (Scotland) Act (SP, 2006) created a statutory obligation to produce a National Planning Framework (NPF) embodying the precepts of sustainable development. The NPF now provides the spatial context for the Scottish Government's own development priorities, articulating the statements of national planning policy set out in Scottish Planning Policy (SPP) (SG, 2010a). Scottish planning legislation places a statutory obligation on SLAs in their capacity as planning authorities to take the NPF and SPP into account in preparing development plans, with the contents of these documents forming a material consideration in determining planning applications.

In parallel with legislation to update the Scottish planning system to enable it to promote sustainable development, the Environmental Assessment (Scotland) Act (EASA) 2005 (SP, 2005) has extended the EU Strategic Environmental Assessment (SEA) Directive (CEC, 2001) to virtually all Scottish public sector policies, programmes and strategies (PPSs). Scottish Ministers promoted this legislation to make Scotland 'a world leader' in using such techniques to mainstream the environment in public sector policy-making (Jackson \& Illsley, 2006). Before any Scottish PPS can now be implemented, it must be subject to an environmental assessment process that is open to public scrutiny and comment. A Scottish SEA Gateway has been created to facilitate these statutory assessment requirements. 
EASA requires consideration of climatic factors when applying SEA to Scottish PPSs, including all Scottish development plans (SG, 2010b). Recently issued guidance on the use of the technique to this end identifies opportunities to:

- explore the potential contribution a PPS makes to GHG emissions, with the aim of avoiding or reducing such emissions where possible;

- consider whether future Scottish PPSs are resilient to the effects of climate change;

- identify measures to address any adverse effects a PPS may have on climate; and

- help the public sector to make informed decisions about how to reduce the GHG emissions of PPSs and ensure they are resilient to the future climate (SG, 2010c: para.1.4).

Scottish Ministers are currently actively reviewing how Scottish SEA procedures might be further extended to meet the statutory obligations of the CCSA. The potential of environmental modelling software packages is being evaluated (Savills, AEA Technology \& MVA Consultancy, 2011). If such approaches are adopted, they would generate quantitative data to supplement the qualitative procedures recommended in current guidance, enabling different development scenarios to be tested for their environmental and carbon footprints.

Initiatives drawing on these techniques to model the resource and carbon implications of SLA operations are already being pursued. The Local Footprint Project, managed by WWF Scotland and the Sustainable Scotland Network, is currently working in partnership with Eco-Schools Scotland, the Improvement Service and Scottish Power, to promote the use of the Resources and Energy Analysis Programme (REAP) interactive resource and carbon accounting software package developed by the Stockholm Environment Institute (Paul et al, 2008). Such software packages are capable of utilising datasets based on environmental input-output data that can be configured for local circumstances.

Such tools can be used to enhance SLA capacity to identify and implement low energy strategies for meeting their new CRC obligations, and help them manage other aspects of their carbon plans more effectively. They can also be used to run alternative scenarios for new development strategies, allowing the strategic options within a development plan to be tested for their ecological and carbon footprints. This makes the climate change 
implications of SLA policy choices much more explicit and subject to detailed examination. South Lanarkshire Council (2010) has undertaken a pathfinder project which applies these carbon footprinting techniques to the masterplans being developed in three of its Community Growth Areas: East Kilbride, Hamilton and Newton.

\section{Conclusions: SLA Opportunities and Threats Posed by Climate Change}

Climate change poses a major challenge for systems of local governance. Local authorities across the world must justify the confidence shown by central governments in their capacity to deliver crucial components of the solution to this problem. Scotland offers a test-bed for judging whether local governance can respond to this challenge, since SLAs have been given a central role in implementing what the Scottish Government considers "world-leading legislation which can act as an example of best practice to other countries" (SG, 2010d: para.4.1).

The common-pool characteristics of climate change management ensure that affordability will remain a crucial determinant of the demonstration effect of this legislation. Assuming central government continues to set the parameters for national energy and transport policies, many of the remaining elements of a cost-effective strategy can be delivered through a decentralised approach, allowing local governance to identify the mitigation and adaptation measures that best suit their own communities. Domestic energy efficiency is an obvious example, as the Local Government Association for England and Wales recognises:

\footnotetext{
through their land-use powers, local development frameworks, regeneration and area action plans, councils are already setting out how their communities will develop and improve over the next few decades. They are uniquely placed to understand when and where improvements are going to be made - and as such, they are best placed to identify opportunities to integrate the installation of energy efficiency measures into these improvements (LGA, 2009: 6).
}

Compared with the UK average, Scotland has a colder climate, more housing in rural locations without access to gas mains, and more households living in dwellings with nonstandard construction that is difficult to insulate. Its domestic energy efficiency schemes need to be carefully tailored to local circumstances, with SLA housing officers focusing on households likely to be exposed to fuel poverty from rising energy costs (Stewart, 2010). Many climate change adaptation measures also require local responses shaped to specific types of area-based hazards. SLA spatial planners and emergency planning services provide the local expertise to identify which communities exposed to climate 
change risks are capable of reinforcing their current defences at reasonable cost, and which might need to relocate or modify some of their activities.

Reliance on local governance to deliver the bulk of community-based mitigation and adaptation measures also accords with the argument made in the paper that policies must address the consumption determinants of carbon emissions rather than their production. Unless individual jurisdictions or trading blocs are prepared to place border taxes on imports of high carbon goods and services - a measure advocated by Helm (2010a) but unlikely to find widespread political support amongst the electorates that bear the costs of such actions - mitigation strategies must ultimately be focused on changing patterns of consumption so that producers, wherever located, will be obliged to adjust their product mixes accordingly. A low carbon world in a global economy which continues to enjoy the benefits of free trade is only possible if this also becomes a low carbon-consumption world, in which the location of production for meeting consumer needs is determined by where carbon inputs are lowest.

Local governance helps provide a suitable framework for promoting such a low carbonconsumption world. A large part of consumer expenditure in any country is directed towards local public services such as education, public health and water supplies, social housing, environmental health and waste management, all of which are susceptible to low carbon modifications. Most of these services are also non-competitive in nature, with local authorities acting as the sole providers to those who live and work in their area. This means that actions SLAs take to promote low carbon-consumption practices cannot readily be undermined by carbon leakages to domestic competitors, as might well occur if private sector businesses such as supermarkets attempted to emulate them. SLAs that succeed in transforming their service delivery from high to low carbon will not lose business to other SLAs who fail to emulate them.

A good example of the ability of local governance to deliver low carbon-consumption strategies is to be found in waste management. In 2010 the Scottish Government published its zero-waste strategy (SG, 2010e). Of the 20 million tonnes of waste produced in Scotland in 2008, domestic households accounted for $14.5 \%$, the construction industry for $43 \%$ and other commercial and industrial sources for $40 \%$. Much of this is capable of being re-used, recycled or used for energy generation rather than be disposed of via landfill, allowing Scotland to reduce both its ecological and its 
carbon footprint. In the 1990 s, Scotland used to send over $80 \%$ of its municipal waste to landfill. Under its new zero-waste strategy, a maximum of 5\% is designated for landfill (SG, 2010e).

In recent years, EU Directives transposed into Scottish legislation have had a major impact on Scottish municipal, commercial and industrial waste management practices (Brady \& Jackson, 2003). Most private sector waste is now managed on a low carbon basis. SLAs are responsible for collecting household waste, and their municipal waste operations also serve a wide range of commercial and industrial undertakings. Following changes in SLA waste collection practices, Scottish households now sort their waste into different bins for kerbside collection and make use of SLA recycling centres. As Table 3 demonstrates, this has triggered a significant low carbon behavioural change by Scottish households over a relatively short time-span.

Table 3. Percentage in Scottish Housing Survey who reported recycling waste items in past month

\begin{tabular}{|l|c|c|c|c|c|c|}
\hline \multirow{2}{*}{\multicolumn{1}{|c|}{ Item }} & \multicolumn{2}{c|}{$\begin{array}{c}\text { Adult } \\
\text { respondents }\end{array}$} & \multicolumn{4}{c|}{ Households } \\
\cline { 2 - 7 } & 2000 & 2002 & 2003 & 2007 & 2008 & 2009 \\
\hline Newspapers/magazines/paper/card & 30 & 33 & 45 & 81 & 83 & 84 \\
Glass bottles and jars & 29 & 31 & 35 & 67 & 70 & 73 \\
Plastic bottles & 6 & 8 & 12 & 58 & 65 & 71 \\
Metal cans & 9 & 10 & 14 & 59 & 65 & 69 \\
\hline One or more of the above items & $\mathbf{4 3}$ & $\mathbf{4 5}$ & $\mathbf{5 5}$ & $\mathbf{8 4}$ & $\mathbf{8 7}$ & $\mathbf{8 8}$ \\
\hline
\end{tabular}

Source: Natural Scotland, 2010

Despite these opportunities, a shortage of finance is likely to prove the main constraint on the ability of SLAs to deliver their climate change duties over the next decade. The introduction of the CRC will highlight ongoing disparities in SLA in-house energy efficiency. The CRC levy should make win-win outcomes from increased in-house energy efficiency even more apparent in an era of rising energy costs. However, SLAs will still need to find the funds to invest in new estate and to recruit and train staff capable of identifying low carbon options (Richens, 2010).

In straightened financial circumstances it is tempting to cut back on training and to accept the lowest upfront construction price for new estate, overlooking options that offer much lower life-cycle outlays. As Audit Scotland (2010: para.69) observes: "public bodies are facing difficult decisions due to increasing financial pressures in the public 
sector and this may make it more difficult to secure the investment needed to continually reduce emissions from energy sources". The challenge facing SLAs such as the Fife and Highland Councils is to find the means to fulfil their statutory obligations with regard to climate change while restructuring to cope with sharp reductions in funding. It will be a good test of the resilience of Scottish local governance.

\section{References}

AEA (2008) Mitigating Against Climate Change in Scotland: Identification and Initial Assessment of Policy Options, Ayrshire, Atomic Energy Authority

Audit Scotland (2010) Improving Energy Efficiency: a Follow-up Report, Edinburgh, Audit Scotland

Barker T \& Johnstone N (1998) “International competitiveness and carbon taxation”, in Barker T \& Köhler J eds. (1998) International Competitiveness and Environmental Policies, Cheltenham, Edward Elgar, 71-142

Barkin J S \& Shambaugh G E (1996) "Common-pool resources and international environmental politics", Environmental Politics, 5(3), 429-447

Bradshaw G \& Johnston A (2009) Carbon Trading Council Taking Stock, London, Local Government Information Unit

Brady S \& Jackson T (2003) "Waste recovery using Packaging Waste Recovery Notes: a costeffective way of meeting targets?" Journal of Environmental Planning and Management, 46(4), 605-619

Brinkley A \& Less S (2010) Carbon Omissions: Consumption-based Accounting for International Carbon Emissions, London, Policy Exchange

CEC (2001) Directive 2001/42/EC of the European Parliament and of the Council on the Assessment of the effects of Certain Plans and Programmes on the Environment, Brussels, Commission of the European Communities

CEC (2002) Directive 2002/91/EC on the Energy Performance of Buildings, Brussels, Commission of the European Community

CEC (2010) Directive 2010/31/EU on the Energy Performance of Buildings (recast), Brussels, Commission of the European Community

Dawkins E, Roelich K, Barrett J \& Baiocchi G (2010) Securing the Future - the Role of Resource Efficiency, Banbury, Oxon, Waste \& Resources Action Programme (WRAP)

DECC (2010a) Beyond Copenhagen: the UK Government's International Climate Change Action Plan, Cm 7850, London, Department of Energy and Climate Change

DECC (2010b) Electricity Market Reform: Consultation Document, Cm 7983, London, Department of Energy and Climate Change

DECC (2010c) Consultations on Amendments to the CRC Energy Efficiency Scheme Order 2010, London, Department of Energy and Climate Change

DECC (2010d) The Green Deal: a Summary of the Government's Proposals, London, Department of Energy and Climate Change

Dresner S \& Ekins P (2006) "Economic instruments to improve UK home energy efficiency without negative social impacts", Fiscal Studies, 27(1), 47-74

Environmental Audit Committee (EAC) (2010) Adapting to Climate Change: Sixth Report of Session 2009-10, London, House of Commons

FC (2010) 2009/10 Progress Report on Scotland's Climate Change Declaration, Glenrothes, Fife Council 
Hayman A (2010) "Minister outlines council role in delivering energy saving scheme", Local Government Chronicle, 25 November, 10-12

HC (2010) Adapting to Climate Change 2010, Inverness, Highland Council

Helm D (2008) “Climate-change policy: why has so little been achieved?", Oxford Review of Economic Policy, 24(2), 211-238

Helm D (2010a) “The case for carbon taxes", in Less S ed. Greener, Cheaper, London, Policy Exchange, 53-78

Helm D (2010b) "Government failure, rent-seeking, and capture: the design of climate change policy”, Oxford Review of Economic Policy, 26(2), 182-196

Helm D R, Phillips J \& Smale R (2007) Too Good to be True: the UK's Climate Change Record, http://www.dieterhelm.co.uk, accessed 5 January 2011

Jackson T \& Illsley B M (2006) "Strategic environmental assessment as a tool of environmental governance: Scotland's extension of the European Union SEA Directive", Journal of Environmental Planning and Management, 49(3), 361-383

Lea R (2011) “Energy shake-up will lift electricity bills to $£ 1,000$ in 20 years”, The Times, 3 January, 35

LGA (2009) From Kyoto to Kettering, Copenhagen to Croydon: Local Government's Manifesto for Building Low-carbon Communities, London, Local Government Association

Mabey N, Hall S, Smith C \& Gupta S (1997) Argument in the Greenhouse: The International Economics of Controlling Global Warming, London, Routledge

McIlveen R (2010) "Cutting the cost of carbon", in Less S ed Greener, Cheaper, London, Policy Exchange, 14-51

Natural Scotland (2010) Key Scottish Environmental Statistics 2010, Edinburgh, Scottish Government

Paul A, Minx J, Owen A, Barrett J \& Wiedman T (2008) Right Climate for Change: Carbon Footprinting for Scottish Local Authorities, Stirling, Local Footprints: Footprinting Support for Local Authorities

PCCC (2010) Planning for Climate Change - Guidance and Model Policies for Local Authorities, London, Planning and Climate Change Coalition

Richens J (2010) “What does the future hold for the CRC?”, ENDS Report, 431, 4-9

Savills, AEA Technology \& MVA Consultancy (2011) Quantitative Greenhouse Gas Impact Assessment: a Tool for Spatial Planning Policy Development. Phase 1: Feasibility Report, Edinburgh, Scottish Government Social Research

SCCD (2011) Scottish Climate Change Declaration, http://climatechange.sustainablescotalnd.net, accessed 14 January

SCCIP (2011) Scottish Climate Change Impacts Partnership, http://www.sccip.org.uk, accessed 14 January

Schreurs M A, Selin H \& VanDeveer S D eds (2009) Transatlantic Environment and Energy Politics: Comparative and International Perspectives, Farnham Surrey, Ashgate

SG (2009a) Climate Change Delivery Plan: Meeting Scotland's Statutory Climate Change Targets, Edinburgh, Scottish Government

SG (2009b) Scotland's Climate Change Adaptation Framework, Edinburgh, Scottish Government

SG (2009c) Conserve and Save: the Energy Efficiency Action Plan for Scotland, Edinburgh, Scottish Government

SG (2010a) Scottish Planning Policy, Edinburgh, Scottish Government

SG (2010b) Strategic Environmental Assessment of Development Plans: Planning Advice Note (PAN) 1/2010, Edinburgh, Scottish Government

SG (2010c) Consideration of Climatic Factors Within Strategic Environmental Assessment (SEA), Edinburgh, Scottish Government Environmental Assessment Team 
SG (2010d) Climate Change in Scotland Annual Report 2009-2010, Edinburgh, Scottish Government.

SG (2010e) Scotland's Zero Waste Plan, Edinburgh, Scottish Government.

SG (2011) Public Bodies Climate Change Duties: Putting Them into Practice: Guidance Required by Part 4 of the Climate Change (Scotland) Act 2009, Edinburgh, Scottish Government.

SNIFFER (2011) Scotland and Northern Ireland Forum for Environmental Research, http://www.sniffer.org.uk, accessed 14 January

South Lanarkshire Council (2010) Ecological Footprinting for South Lanarkshire Community Growth Areas, Hamilton, South Lanarkshire Planning and Building Standards Services

SP (2005) The Environmental Assessment (Scotland) Act 2005, Edinburgh, Scottish Parliament

SP (2006) The Planning etc. (Scotland) Act 2006, Edinburgh, Scottish Parliament

SP (2008) The Energy Performance of Buildings (Scotland) Regulations 2008, Edinburgh, Scottish Parliament

SP (2009) Climate Change (Scotland) Act 2009, Edinburgh, Scottish Parliament

Stern S N (2006) The Stern Review on the Economics of Climate Change, London, H M Treasury

Stewart D (2010) The Issues and Challenges in Delivering More Energy Efficient Housing in Scotland, Glasgow, Scottish Centre for Regeneration Briefing Paper 19

UK Parliament (2008) UK Climate Change Act 2008: Chapter 27 - Climate Targets and Budgeting, the Committee on Climate Change, Trading Schemes, Impact of and Adaptation to Climate Change, etc., London, Palace of Westminster

Wilson E \& Piper J (2010) Spatial Planning and Climate Change, Abingdon, Routledge. 